\title{
Front Matter: Volume 7166
}

, "Front Matter: Volume 7166," Proc. SPIE 7166, Optics in Bone Biology and Diagnostics, 716601 (16 March 2009); doi: 10.1117/12.827221

SPIE. Event: SPIE BiOS, 2009, San Jose, California, United States 


\section{PROGRESS IN BIOMEDICAL OPTICS AND IMAGING}

Vol. 10, No. 6

\section{Optics in Bone Biology and Diagnostics}

Andreas Mandelis

Editor

24 January 2009

San Jose, California, United States

Sponsored and Published by

SPIE

Volume 7166

Proceedings of SPIE, 1605-7422, v. 7166

SPIE is an international society advancing an interdisciplinary approach to the science and application of light. 
The papers included in this volume were part of the technical conference cited on the cover and title page. Papers were selected and subject to review by the editors and conference program committee. Some conference presentations may not be available for publication. The papers published in these proceedings reflect the work and thoughts of the authors and are published herein as submitted. The publisher is not responsible for the validity of the information or for any outcomes resulting from reliance thereon.

Please use the following format to cite material from this book:

Author(s), "Title of Paper," in Optics in Bone Biology and Diagnostics, edited by Andreas Mandelis, Proceedings of SPIE Vol. 7166 (SPIE, Bellingham, WA, 2009) Article CID Number.

ISSN 1605-7422

ISBN 9780819474124

Published by

SPIE

P.O. Box 10, Bellingham, Washington 98227-0010 USA

Telephone +1 3606763290 (Pacific Time) · Fax +1 3606471445

SPIE.org

Copyright $@ 2009$, Society of Photo-Optical Instrumentation Engineers.

Copying of material in this book for internal or personal use, or for the internal or personal use of specific clients, beyond the fair use provisions granted by the U.S. Copyright Law is authorized by SPIE subject to payment of copying fees. The Transactional Reporting Service base fee for this volume is $\$ 18.00$ per article (or portion thereof), which should be paid directly to the Copyright Clearance Center (CCC), 222 Rosewood Drive, Danvers, MA 01923. Payment may also be made electronically through CCC Online at copyright.com. Other copying for republication, resale, advertising or promotion, or any form of systematic or multiple reproduction of any material in this book is prohibited except with permission in writing from the publisher. The CCC fee code is 1605$7422 / 09 / \$ 18.00$.

Printed in the United States of America.

Publication of record for individual papers is online in the SPIE Digital Library.

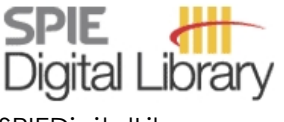

SPIEDigitalLibrary.org

Paper Numbering: Proceedings of SPIE follow an e-First publication model, with papers published first online and then in print and on CD-ROM. Papers are published as they are submitted and meet publication criteria. A unique, consistent, permanent citation identifier (CID) number is assigned to each article at the time of the first publication. Utilization of CIDs allows articles to be fully citable as soon they are published online, and connects the same identifier to all online, print, and electronic versions of the publication. SPIE uses a six-digit CID article numbering system in which:

- The first four digits correspond to the SPIE volume number.

- The last two digits indicate publication order within the volume using a Base 36 numbering system employing both numerals and letters. These two-number sets start with 00, 01, 02, 03, 04, $05,06,07,08,09,0 A, 0 B \ldots$. OZ, followed by 10-1Z, 20-2Z, etc.

The CID number appears on each page of the manuscript. The complete citation is used on the first page, and an abbreviated version on subsequent pages. Numbers in the index correspond to the last two digits of the six-digit CID number. 


\section{Contents}

vii Conference Committee

\section{SESSION 1 BONE SPECTROSCOPY AND OPTICAL PROCESSES I}

716602 Vibrational spectroscopy in biomedical science: bone (Invited Paper) [7166-01] S. Gamsjäger, R. Zoehrer, P. Roschger, Ludwig Boltzmann Institute of Osteology at the Hanusch Hospital (Austria); P. Fratzl, Max Planck Institute for Colloids and Interfaces (Germany); K. Klaushofer, Ludwig Boltzmann Institute of Osteology at the Hanusch Hospital (Austria); R. Mendelsohn, Rutgers Univ. (United States); E. P. Paschalis, Ludwig Boltzmann Institute of Osteology at the Hanusch Hospital (Austria)

716604 Monte Carlo modeling of photon transport in buried bone tissue layer for quantitative Raman spectroscopy [7166-03]

R. H. Wilson, K. A. Dooley, M. D. Morris, M.-A. Mycek, Univ. of Michigan, Ann Arbor (United States)

716605 Automated Raman spectral preprocessing of bone and other musculoskeletal tissues [7166-04]

F. W. L. Esmonde-White, Univ. of Michigan, Ann Arbor (United States); M. V. Schulmerich, Univ. of Michigan, Ann Arbor (United States) and Univ. of Illinois at Urbana-Champaign (United States); K. A. Esmonde-White, M. D. Morris, Univ. of Michigan, Ann Arbor (United States)

\section{SESSION 2 BONE SPECTROSCOPY AND OPTICAL PROCESSES II}

716606 Raman analysis of yield in cortical bone [7166-05]

J. H. Jeon, Purdue Univ. (United States); V. J. Korlepara, Mako Surgical Corp. (United States); J. Blendell, O. Akkus, Purdue Univ. (United States)

716607 Raman spectroscopy of murine bone in response to simulated spaceflight conditions [7166-06]

G. S. Mandair, Univ. of Michigan, Ann Arbor (United States); T. A. Bateman, Clemson Univ. (United States); M. D. Morris, Univ. of Michigan, Ann Arbor (United States)

716608 Polarization-sensitive optical coherence tomography in equine bone [7166-07]

J. W. Jacobs, S. J. Matcher, Kroto Research Institute (United Kingdom)

\section{SESSION 3 PHOTONIC PROCESSES IN BONE AND DENTAL TISSUES I}

7166 OA Dynamic photophysical processes in laser irradiated human cortical skull bone [7166-10] A. Mandelis, C.-H. Kwan, A. Matvienko, Univ. of Toronto (Canada) 
7166 OB Raman spectroscopy for assessment of bone quality in MMP-2 knockout mice [7166-11] X. Bi, J. S. Nyman, C. A. Patil, P. Masui, C. Lynch, A. Mahadevan-Jansen, Vanderbilt Univ. (United States)

7166 0C Quantitative analysis of incipient mineral loss in hard tissues [7166-12] A. Matvienko, A. Mandelis, A. Hellen, R. Jeon, Univ. of Toronto (Canada) and Quantum Dental Technologies, Inc. (Canada); S. Abrams, Quantum Dental Technologies, Inc. (Canada); B. Amaechi, Univ. of Texas Health Science Ctr. at San Antonio (United States)

7166 OE Caries assessment: establishing mathematical link of clinical and benchtop method [7166-14]

B. T. Amaechi, Univ. of Texas Health Science Ctr. at San Antonio (United States)

7166 OF Quantum dots as mineral- and matrix-specific strain gages for bone biomechanical studies [7166-16]

P. Zhu, J. Xu, M. Morris, A. Ramamoorthy, N. Sahar, D. Kohn, Univ. of Michigan, Ann Arbor (United States)

\section{SESSION $5 \quad$ IMAGING DIAGNOSTICS OF BONES AND TEETH}

7166 OG Tomographic x-ray-guided three-dimensional diffuse optical imaging of osteoarthritis in the finger joints: a clinical study (Invited Paper) [7166-17]

Z. Yuan, H. Jiang, Q. Zhang, E. S. Sobel, H. Jiang, Univ. of Florida (United States)

$7166 \mathrm{OH} \quad$ Photothermal and infrared thermography characterizations of thermal diffusion in hydroxyapatite materials [7166-18]

J. Bante-Guerra, M. Conde-Contreras, S. Trujillo, P. Martínez-Torres, Ctr. de Investigación y de Estudios Avanzados del IPN (Mexico); B. Cruz-Jimenez, Univ. Autónoma de Yucatán (Mexico); P. Quintana, J. J. Alvarado-Gil, Ctr. de Investigación y de Estudios Avanzados del IPN (Mexico)

$71660 \mathrm{Ol}$ Characterizing light propagation in bone for photodynamic therapy of osteosarcoma [7166-19]

V. M. Rossi, Oregon State Univ. (United States) and Oregon Health \& Science Univ. (United States); S. B. Gustafson, VCA Raleigh Hills Animal Hospital (United States);

S. L. Jacques, Oregon Health \& Science Univ. (United States)

$71660 \mathrm{~J} \quad$ Osteoarthritis screening using Raman spectroscopy of dried human synovial fluid drops [7166-20]

K. A. Esmonde-White, G. S. Mandair, F. W. L. Esmonde-White, F. Raaii, B. J. Roessler, M. D. Morris, Univ. of Michigan, Ann Arbor (United States)

7166 OK Three-dimensional diffuse optical tomography of osteoarthritis: a study of 38 finger joints [7166-21]

Q. Zhang, Z. Yuan, E. S. Sobel, H. Jiang, Univ. of Florida (United States) 
POSTER SESSION

$7166 \mathrm{OL}$ Assessment of a new biomimetic scaffold and its effects on bone formation by OCT [7166-08]

Y. Yang, Keele Univ. School of Medicine (United Kingdom); H. M. Aydin, E. Piskin, Hacettepe Univ. and Biyomedtek (Turkey); A. J. El Haj, Keele Univ. School of Medicine (United Kingdom)

Author Index 
Downloaded From: https://www.spiedigitallibrary.org/conference-proceedings-of-spie on 26 Apr 2023

Terms of Use: https://www.spiedigitallibrary.org/terms-of-use 


\title{
Conference Committee
}

\author{
Symposium Chairs \\ James G. Fujimoto, Massachusetts Institute of Technology \\ (United States) \\ R. Rox Anderson, Wellman Center for Photomedicine, Massachusetts \\ General Hospital (United States) and Harvard Medical School \\ (United States)
}

Program Track Chair

Reza S. Malek, Mayo Clinic (United States)

Conference Chair

Andreas Mandelis, University of Toronto (Canada)

Program Committee

Robert R. Alfano, City College/CUNY (United States)

Angela Cheung, University Health Network/Mount Sinai Hospital (Canada)

Peter Fratzl, Max Planck Institute, Potsdam (Germany)

Huabei Jiang, University of Florida (United States)

Stephen J. Matcher, The Kroto Institute, The University of Sheffield (United Kingdom)

Michael D. Morris, University of Michigan (United States)

Eleftherios P. Paschalis, Ludwig Boltzmann Institute of Osteology, Vienna (Austria)

George Sandor, Hospital for Sick Children, Toronto (Canada)

Session Chairs

1 Bone Spectroscopy and Optical Processes I

Andreas Mandelis, University of Toronto (Canada)

2 Bone Spectroscopy and Optical Processes II

Qizhi Zhang, University of Florida (United States)

3 Photonic Processes in Bone and Dental Tissues I

Andreas Mandelis, University of Toronto (Canada) 
$4 \quad$ Photonic Processes in Bone and Dental Tissues II

Michael D. Morris, University of Michigan (United States)

$5 \quad$ Imaging Diagnostics of Bones and Teeth

Stephen J. Matcher, The University of Sheffield (United Kingdom) 